\title{
Bioactive composition, antifungal, antioxidant, and anticancer potential of agarwood essential oil from decaying logs (Gyrinops spp.) of Papua Island (Indonesia)
}

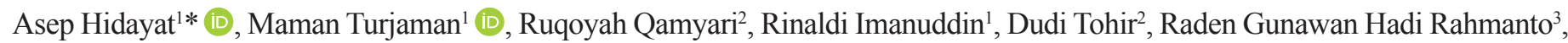 \\ Arida Susilowati ${ }^{4}$ (D) \\ ${ }^{1}$ Forest Research and Development Center, Forest Research and Development Agency, Ministry of Environmental and Forestry, Bogor, Indonesia. \\ ${ }^{2}$ Department of Chemistry, Faculty of Mathematics and Natural Sciences, Bogor Agricultural University, Bogor, Indonesia. \\ ${ }^{3}$ Forest Products Research and Development Center, Forest Research and Development Agency, Ministry of Environmental and Forestry. Bogor, Indonesia. \\ ${ }^{4}$ Faculty of Forestry, University of Sumatera Utara, Medan, Indonesia.
}

\begin{tabular}{l}
\hline ARTICLE INFO \\
\hline Received on: 16/04/2021 \\
Accepted on: $20 / 07 / 2021$ \\
Available Online: 03/10/2021 \\
\\
\hline Key words: \\
Gyrinops, gaharu, distillation, \\
fungal-induction, volatile \\
compounds.
\end{tabular}

\section{INTRODUCTION}

Agarwood, locally known as gaharu in Indonesia, is the name for the impregnated heartwood resin produced by the genera Aquilaria and Gyrinops (Gong and Guo, 2009). It has been in high demand due to its special usage in premium perfume ingredients, aromatherapy, pharmaceuticals, herbal medicines, and religious ceremonies for centuries. Six from the total of 29 species in the genus Aquilaria (Saikia and Khan, 2013; Soehartono and Newton,

\footnotetext{
*Corresponding Author

Asep Hidayat, Forest Research and Development Center, Forest Research and Development Agency, Ministry of Environmental and Forestry, Bogor, Indonesia.E-mail: ashephidayat12@gmail.com
}

2001) and seven from the total of nine species in the Gyrinops genus are known to grow naturally in Indonesia (Barden et al., 2000). In Indonesia, the central site of agarwood trade has been shifted based on the abundance of wild agarwood extraction in certain locations. In the years 1918-1925 (Dwiprabowo et al., 2016; Perdanahardja, 2008), agarwood trade was located at Tanjung Selor and Tarakan (North Kalimantan), Tanjung Redeb, Pekanbaru and Siak Indrapura (Riau-Sumatera), Belitung Island, and Kumai Pontianak. Nowadays, the center of agarwood trade has been shifted to the eastern part of Indonesia, specifically Sulawesi and Papua Island, with the product coming from the genus Gyrinops spp. (Mulyaningsih and Yamada, 2007), and the trading name is known as "malakensis" and "filaria" (Turjaman et al., 2016). 
In Papua Island, the eastern part of Indonesia, it was reported that agarwood originated from two parts of the island, Northern and Southern Papua, and they were identified as Aquilaria filaria and Gyrinops spp. (Boissière et al., 2004). The Jayawijaya Mountain Belt separates the island into two parts and those may be the cause of different species growing in different parts (Mulyaningsih and Yamada, 2007). Since 2000, the population of $A$. filaria originating from the southern part of Papua has been recorded to decline sharply for a number of reasons (i.e., overexploitation, high demand from consumers, and good livelihood for the forest communities). Related to the occurrence of $A$. filaria, there were three periods of agarwood harvesting in Southern Papua (Semiadi et al., 2010): (1) agarwood harvesting by clear-cutting all standing trees which were practiced before 1999 , (2) collection of residual tree pieces left in the field from previous periods of harvesting which were practiced during 1999-2003, and (3) digging up a burden stump, also known as a decaying log, from the average depth of 100-200 $\mathrm{cm}$ which has been practiced since 2004 up to the present time. Based on the legal document record of agarwood production issued by BBKSDA Papua (Forest Resource Conservation Agency of Papua, Ministry of Environment and Forestry), the volume of agarwood originating from decaying logs for the kemedangan tree class (lowest grade) can reach 100 tons/ year. Before 2020, definitive species for traded agarwood from Papua have been unidentified and only listed by their trading name "filaria." Based on the latest species identification (Sugiyanto et al., 2018), decaying logs originated from the genus Gyrinops, with the quota export for Indonesia given by CITES reaching up to 1,000 tons/year.

Agarwood essential oil (AEO) is an oil extracted from the agarwood tree. It is obtained by distillation and is the most principal ingredient for premium perfumes due to its unique fragrance and long-lasting odor. Several studies have been previously conducted to determine AEO qualities (Ismail et al., 2014), to enhance AEO yield by several pretreatments (Yoswathana et al., 2012), and to investigate its phytochemical constituents and their bioactive properties (Abdullah et al., 2007; Ahmaed et al., 2017; Azah et al., 2008; Chen et al., 2012; Dahham et al., 2015; Hashim et al., 2014; Hoque et al., 2018; Ibrahim et al., 2011; Ismail et al., 2014; Radzi et al., 2018; Tajuddin and Yusoff, 2010; Thuy et al., 2019; Wang et al., 2018; Zhang et al., 2014a). On the contrary, there is no record of the study on AEO originating from decaying logs (Gyrinops spp.). However, there were reports on several Gyrinops species that produced agarwood resin, i.e., Gyrinops walla, Gyrinops salicifolia, and Gyrinops versteegii (Faizal et al., 2020; Subasinghe et al., 2012), which led to the necessity for further investigations. This study was conducted to evaluate the chemical composition and bioactive potential of AEO from decaying logs (Gyrinops sp.), as well as to make comparisons of AEO from 1.5-year-old inoculated Aquilaria malaccensis and that commercial AEO available in the common market.

\section{MATERIALS AND METHODS}

\section{Plant materials and chemicals}

A decaying log (M1) of agarwood from the forest of Asmat District, Papua, was collected for this research (Fig. 1). A comparison was carried out with other AEOs from different sources, namely M2 AEO and M3 AEO. The agarwood was obtained from 1.5-year-old inoculated A. malaccensis, while the AEO was distilled from its unaffected heartwood samples of the 1.5-year-old inoculated A. malaccensis (M2) which were considered to have the lowest agarwood qualities. The common commercial AEO (M3) of $A$. malaccensis was purchased from agarwood farmers in Lingga Island, Riau Archipelago, originating from the hydrodistillation process of 3-year-old inoculated agarwood. Chemicals including alcohol, potato dextrose agar (PDA), glycerol 20\%, Folin-Ciocalteu, dimethylsulfoxide (DMSO), methanol, and 1,1-diphenyl-2-picrylhydrazyl (DPPH) were used at commercial grades.

\section{Water distillation extraction}

The air-dried agarwood samples (100 g) were processed to become powder, then sieved using 60-mesh sieves, and soaked overnight in water. The agarwood oil was obtained by hydrodistillation according to the Zhang et al. (2014a) methods. The extracted essential oil then was separated and stored at $-4^{\circ} \mathrm{C}$ in a freezer prior to further analysis.

\section{Chemical constituent analysis}

The chemical constituent of the AEO was identified using gas chromatography (Shimadzu, GC-FID model 2014). Chemical constituent separation was carried out with a TC-5 capillary column $(30 \mathrm{~m}$, id $\times 0.25 \mathrm{~mm})$. Helium was the carrier gas and was delivered with a column pressure of $100 \mathrm{kPa}$, at a constant flow rate of $1.5 \mathrm{ml} \mathrm{minute^{-1 }}$ and temperature of interface at $280^{\circ} \mathrm{C}$. The initial temperature was $60^{\circ} \mathrm{C}$, was followed by an

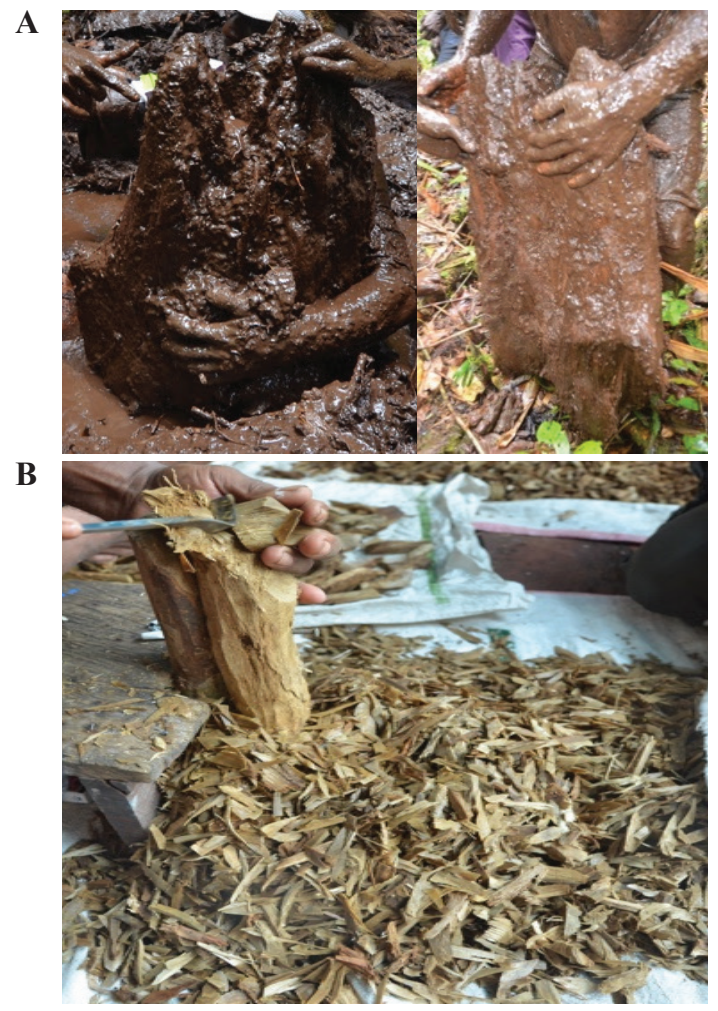

Figure 1. Decaying log, Gyrinops spp., used for extracted AEO (M1). Harvesting (A) and grading $(\mathrm{B})$ process. 
increase from $10^{\circ} \mathrm{C}$ minute ${ }^{-1}$ to $280^{\circ} \mathrm{C}$, and then was kept at $280^{\circ} \mathrm{C}$ for 10 minutes. The injector temperature was maintained at $280^{\circ} \mathrm{C}$ and the injection volume was $2 \mathrm{ml}$. The identification of individual components was carried out by comparing and analyzing their retention times with some authentic samples and retention indices related to the n-hydrocarbons series (Hübschmann et al., 2009).

\section{Antifungal assay}

The AEO antifungal activity was carried out using an agar medium assay according to Philippe et al.'s (2012) method with slight modifications. The AEO was diluted with DMSO to obtain the final range concentrations of 50, 500, and 5,000 $\mathrm{mg} \mathrm{l}^{-1}$ which was $5 \mathrm{ml}$ of PDA in glass Petri dishes $(5 \times 1.5 \mathrm{~cm})$. An agar disk ( $5 \mathrm{~mm}$ diameter) of Fusarium solani was inoculated and incubated at room temperature for 7 days. The negative control (without AEO) was treated with the same procedure. The experiments were carried out in triplicate. The growth inhibition percentage was determined by mycelial growth inhibition using the equation

$$
\text { Inhibition }(\%)=\left[\left(J_{C}-J t\right) / J_{C}\right] \times 100 \text {. }
$$

where $J c$ is radial covered for control and $J t$ is radial covered for the treated sample.

\section{Antioxidant activity assay}

The antioxidant activity of AEO was determined according to previously published methods with slightmodifications (Hidayat et al., 2019). The extract was diluted using a series of test tubes with ethyl acetate to obtain a range of concentration of 0.25 $\mathrm{ml}$ of DPPH $(1 \mathrm{M})$ and was added with methanol to obtain $2.5 \mathrm{ml}$ of final reaction volume. After incubation at room temperature for 30 minutes; the absorbance was monitored at $517 \mathrm{~nm}$. The ethyl acetate solution without extracts was selected as the control. All experiments were conducted in triplicate. The inhibitory activity was analyzed and calculated from $\left[\left(A_{0}-A_{1}\right) / A_{0}\right] \times 100$, where $A_{0}$ is the control absorbance and $A_{1}$ is the extract or standard absorbance. The antioxidant activity was expressed as inhibitory concentration $\left(\mathrm{IC}_{50}\right)$, namely the necessary amount of sample for reducing the concentration of initial DPPH by half.

\section{Cytotoxicity assay}

Cytotoxicity evaluation of AEO was carried out using the 3-(4,5-Dimethylthiazol-2- yl)-2,5-Diphenyltetrazolium Bromide (MTT) assay as described by Mosmann (1983). The exponential growth phase of MCF-7 cells $\left(1 \times 10^{5}\right.$ per $\mathrm{ml}$ of cells $)$ was cultured in a 96-well polystyrene-coated plate containing $100 \mathrm{mg} \mathrm{l}^{-1}$ of agarwood oil and was incubated at $37^{\circ} \mathrm{C}$ for 48 hours in $5 \% \mathrm{CO}_{2}$. After being incubated for 48 hours, $100 \mu \mathrm{l}$ of the MTT reagent was added to each well and continued to incubate until 4 hours. Ethanol was used for dissolving formazan crystals in each well, and absorbance immediately was monitored at $595 \mathrm{~nm}$. The wells containing MTT reagent and complete medium and nanoparticles without cells were used as blanks. Positive control was obtained by using doxorubicin.

\section{Statistical analysis}

All results were presented in their mean values and analyzed using Statistical Package for the Social Sciences (version
15) for Windows. The identification results of the individual compounds of AEO were displayed in a heatmap and biplot graph. The biplot analysis was conducted using two principal factors (F1 and F2) for each AEO compound, while the AEO spectrum was analyzed using JMP statistical software (version 15) for Windows.

\section{RESULTS AND DISCUSSION}

\section{Agarwood essential oil (AEO)}

Agarwood is a resinous heartwood from the Thymelaeaceae family deriving from a wounded part caused by both physical injury and pathogens infection (Jong et al., 2014; Turjaman et al., 2016). The formation of agarwood could be triggered by natural and artificial induction processes. Natural agarwood formation occurs in a very slow process and may take several decades (Jong et al., 2014; Turjaman et al., 2016). Artificial agarwood induction by using a proper technique and formula will produce high-grade agarwood with a quality that closely resembles those obtained from the natural source only in several months or years (Tan et al., 2019). A decaying log (M1) has been identified as the genus Gyrinops based on wood anatomy structures: 1) Wood had cambial variants in the form of scattered insertion of bark, 2-6 multiple oval-shaped vessels with an average diameter of $90.11 \pm 2.59 \mathrm{~m}$. There were recesses between the vessels with opposite radial position. No tylosis found in the part containing agarwood resin. The apotracheal parenchyma was scattered while the paratracheal was sparse. Axial parenchyma $2-5$ cells per strand; 2) Heterocellular radius type with a width of $1-2$ series and an average height of $225 \mu \mathrm{m}$. The frequency of the radius was $9.1 \mathrm{~mm}^{-2}$ and the recesses have dots (Sugiyanto et al., 2018). M1 AEO was originated from a decaying log where agarwood formation might result from a natural process. However, the exact time of agarwood formation itself was still unclear. There were two possibilities for the starting point of formation: (1) the induction occurred when they were still standing trees and then they were cut down and buried under the soil surface or (2) the standing trees were cut down and found to have no agarwood formation and then the abandoned falling trees were slowly buried, and agarwood formation started to occur when they were buried under the soil surface.

In this study, M2 AEO was obtained from 1.5-year-old artificial induction of an $A$. malaccensis tree with the endophytic fungus of $F$. solani. Agarwood formation induced by $F$. solani has also been reported in Aquilaria microcarpa, A. malaccensis, Aquilaria crassna, and Aquilaria beccariana, as well as Gyrinops spp. (Sitepu et al., 2011; Turjaman et al., 2016). The yield of AEO obtained by hydrodistillation of M1 and M2 was $0.079 \%$ $(w / w)$ and $0.084 \%(w / w)$. The AEO for M1, M2, and M3 (control) showed different colors and states at room temperature. At the concentration of 1,000 ppm, M1 and M2 were clear to yellow, aromatic, and paste, while M3 was yellow to brown, aromatic, and liquid at room temperature. The yield of M2 AEO was quite high in volume compared to that of M1. The hydrodistillation employed was the conventional method with some disadvantages such as low yield (Yoswathana et al., 2012). However, it was easily operated by many farmers because it was simple and easy. The differences in M1 and M2 yield were important results because it depended on raw material resin qualities and its compound 
contents (Naef, 2011; Zhang et al., 2012), as well as pretreatments extraction (Yoswathana et al., 2012).

\section{Chemical composition of AEO}

The volatile constituent of AEO was obtained by hydrodistillation as presented in Table 1. From all different AEO sources, a total of 63 chemical constituents were identified consisting of several aromatic, sesquiterpenes, and fatty acids. The abundance of each compound was sourced from sesquiterpene groups (30.90\%-46.39\%). Fifty-eight compounds were determined in M1 (Table 1), representing $48.53 \%$ of the total relative amounts, with the dominant compounds being isoaromadendrene epoxide (2.59), 1,5-epoxy-nor-ketoguaiene $(2.27 \%)$, dehydrojinkoheremol $(2.06 \%)$, and $\alpha$-bisabolol $(2.06 \%)$ for sesquiterpene groups and 2-hexadecanone (1.74\%), tetradecanal $(1.57 \%)$, and pentadecanal $(0.66 \%)$ for fatty acid groups. Fifty-one compounds were also identified in M2 (Table 1), representing $49.99 \%$ of the total relative amounts, with higher compounds being isoaromadendrene epoxide (2.66\%), agarospirol $(4.17 \%)$, 4,4,11,11-tetramethyl-7-tetracyclo[6.2.1.0(3.8)0(3.9)] undecanol $(2.82 \%)$, baimuxinal $(2.17 \%)$, and guaia-1(10),11dien-9-one $(2.33 \%)$ for sesquiterpene groups and tetradecanal $(1.32 \%)$, and tetradecanoic acid $(0.61 \%)$ for fatty acid groups. Fifty-six compounds were identified in M3 (Table 1). AEO was available in the market as a positive control, representing $36.63 \%$ of the total relative amounts. The abundance of compounds was 2,6-dimethoxyphenol $(0.74 \%)$, 3,4-dimethoxyphenol (1.24\%), and vanillin (1.46\%) for aromatic groups; drima-7,9(11)-diene (5.52\%) and $\alpha$-bulnesene $(2.52 \%)$ for sesquiterpene groups; and pentadecanal $(0.69 \%)$ for fatty acid groups. 9,11-Eremophiladien-8-one was only present in $\mathrm{M} 1$, and rotundone was only present in $\mathrm{M} 3$ as a positive control. Although some compounds found were minor or a trace, at least 41 compounds were found in all observed AEOs, such as vanillin, aromadendrene, agarospirol, dehydrojinkoheremol, baimuxinal, selina-3,11-dien-9-ol, selina-3,11-dien14-al, guaia-1(10),11-dien-15-ol, and guaia-1(10),11-dien-15al, while the others were only present in the essential oil of M1 and M2, M1 and M3, or M2 and M3.

Generally, the profile chemical constituents in M1 had a quite similar profile to those in M2, while M1 was different from M3 (Fig. 2). The differences between the essential oils of M1 and M3 were showed in their colors and forms, 12 compounds, 2 aromatic groups ( $p$-vinylanisole and 2-butanone 4-phenyl), 8 sesquiterpene compounds (4-epi-cis-dihydroagarofuran, $\beta$-guaiene, $\Upsilon$-gurjunene, $\Upsilon$-muurolene, eudesm-7(11)-en-4 $\alpha$ ol, rotundone, 9,11-eremophiladien-8-1, and eudesmol), and 2 fatty acid groups (tridecanoic acid and tetradecanoic acid); and the total relative content of the chemical constituent in M3 for all total chemical groups was the lowest except for aromatic groups. Furthermore, there were 12 compounds present in M2 or M3. Those were benzylactone, 2.6-dimethoxyphenol, 4-epi-cis-dihydroagarofuran, drima-7,9(11)-diene, $\beta$-guaiene, $\alpha$-muurolene, eudesm-7(11)-en-4 $\alpha$-ol, 9,11-eremophiladien-8one, selina-3,11-dien-14-ol, dihydrokaranone, pentadecanal, and hexadecanol. The important finding in this study was that at least 10 compounds had been identified to be responsible for a specific agarwood odor, such as agarospirol, dehydrojinkoh-eremol, baimuxinal, selina-3,11-dien-9-ol, selina-3,11-dien-14-al, selina-3,11-dien-14-ol, selina-4,11-dien-14-al, guaia-1(10),11dien-15-ol, dihydrokaranone, and guaia-1(10),11-dien-15-al. These results revealed that the raw material of M1 containing agarwood resin had different chemical constituents from M3.

Although there were differences in the chemical composition found in M1, M2, and M3, they were closely related to previous studies explaining the variation of chemical composition found in AEO. It was determined that M1 AEO had major sesquiterpene components produced by the mitogenactivated protein kinase, signaling pathways which led to the expression of sesquiterpene synthase genes (Rasool and Mohamed, 2016; Xu et al., 2013). In all AEO assays from different sources, 63 compounds could be identified and 58 of them were found in M1 AEO. All of the detected compounds were commonly found in agarwood from different qualities and sources (Ahmaed and Kulkarni, 2017; Chen et al., 2012; Naef, 2011; Tajuddin et al., 2013; Thuy et al., 2019; Wetwitayaklung et al., 2009; Yusoff et al., 2015).

In the market, the AEO quality and grade depend on physical appearance, fixative characteristics, odor, color, and consumer perception, which can only be determined by a trained person (Ismail et al., 2014). This is a conventional method and has been debatable considering its subjectivity, large labor expense, poor reproducibility, and time consumption (Ismail et al., 2014). Other methods to determine AEO grade or quality are by evaluating its chemical composition characteristics (Ishihara and Tsuneya, 1993a, 1993b). Furthermore, Ismail et al. (2014) summarized the component based on the characteristic of the AEO itself. The high quality of the AEO was determined by its high content of $\alpha$-guaiene, (-)-guaia-1(10),11-dien15-al, (-)-selina-3,11-dien,9-one, (+)-selina-3,11-dien,9-ol, eudesmane, $\beta$-agarofuran (the most important compound), $\alpha$-agarofuran, 10-epi- $\gamma$-eudesmol, and sesquiterpene groups (major). The chemical compounds mentioned above were detected to be present in all studied AEOs (M1, M2, and M3), except (-)-selina-3,11-dien,9-one, and 10-epi-r-eudesmol. The relative amount of $\beta$-agarofuran in M3 $(0.589 \%)$ was higher than that of M1 and M2, as well as $\alpha$-guaiene with a relative amount of more than $0.05 \%$. This indicated that both the AEO of M1 and M2 showed high similarity in the form of grade or quality as shown in Figure 2. Among all AEOs studied, M3 AEO was considered to have higher quality. Although the key compounds responsible for classifying AEO quality had been determined in $\mathrm{M} 1, \mathrm{M} 2$, and $\mathrm{M} 3$, the positive correlation results with conventional methods were still undecided.

\section{Bioactive activities}

The antifungal, antioxidant, and cytotoxicity capabilities of M1, M2, and M3 AEO are displayed in Table 2. Antifungal activity was tested against $F$. solani, a plant pathogen and a biological agent for agarwood formation (Sitepu et al., 2011; Turjaman et al., 2016). The antifungal activity of AEO was evaluated by the percentage of minimum growth inhibition $\left(\mathrm{MIG}_{50}\right)$ values. All AEOs inhibiting the growth of $F$. solani with $\mathrm{MIG}_{50}$ ranged from $0.5 \mathrm{mg} \mathrm{ml}^{-1}$ to $6.9 \mathrm{mg} \mathrm{ml}^{-1}$. The strongest antifungal activity was obtained from M1, whereas M3 showed the weakest 
Table 1. The heatmap of relative contents of chemical compounds of AEO of M1, M2, and M3.

\begin{tabular}{|c|c|c|c|c|c|c|}
\hline \multirow{2}{*}{ No } & \multirow{2}{*}{ Compounds } & \multicolumn{3}{|c|}{ Heat map of relative content $(\%)^{a}$} & \multirow[t]{2}{*}{ Retention index (RI) ${ }^{\mathrm{b}}$} & \multirow[t]{2}{*}{ Sources } \\
\hline & & M1 & M2 & M3 & & \\
\hline & Aromatics & 0.283 & 0.133 & 3.978 & & \\
\hline 1 & $p$-vinylanisole & & & & 1,159 & RI (Zhang et al., 2014a) \\
\hline 2 & $p$-metoxypenol & & & & 1,195 & RI (Wetwitayaklung et al., 2009) \\
\hline 3 & 2 butanone 4 phenyl & & & & 1,206 & RI (Wetwitayaklung et al., 2009) \\
\hline 4 & Benzylactone & & & & 1,260 & $\begin{array}{l}\text { RI (Chen et al., 2012; Zhang et al., } \\
\text { 2014a) }\end{array}$ \\
\hline 5 & 2,6 dimethoxyphenol & & & & 1,302 & RI (Ahmaed et al., 2017) \\
\hline 6 & 3,4-dimethoxyphenol & & & & 1,310 & RI (Wetwitayaklung et al., 2009) \\
\hline \multirow[t]{2}{*}{7} & Vanilin & & & & 1,419 & RI (Chen et al., 2012) \\
\hline & Sesquiterpenes & 42.835 & 46.390 & 30.904 & & \\
\hline 8 & $\beta$-Maaliene & & & & 1,414 & RI (Yusoff et al., 2015) \\
\hline 9 & $\Upsilon$-selinene & & & & 1,437 & $\begin{array}{l}\text { RI (Wetwitayaklung et al., 2009; } \\
\text { Yusoff et al., 2015) }\end{array}$ \\
\hline 10 & $\alpha$-guaiene & & & & 1,440 & RI (Yusoff et al., 2015) \\
\hline 11 & Aromadendrane & & & & 1,445 & RI (Yusoff et al., 2015) \\
\hline 12 & Humulena & & & & 1,446 & $\begin{array}{c}\text { RI (Wetwitayaklung et al., 2009; } \\
\text { Yusoff et al., 2015) }\end{array}$ \\
\hline 13 & 4 epi cis dihydroagarofuran & & & & 1,452 & RI (Ahmaed et al., 2017) \\
\hline 14 & Drima-7,9(11)-diene & & & & 1,458 & RI (Wetwitayaklung et al., 2009) \\
\hline 15 & $\beta$-guaiene & & & & 1,467 & RI (Yusoff et al., 2015) \\
\hline 16 & Valencene & & & & 1,469 & RI (Ahmaed et al., 2017) \\
\hline 17 & $\Upsilon$-gurjunene & & & & 1,471 & RI (Yusoff et al., 2015) \\
\hline 18 & $\beta$-agarofuran & & & & 1,473 & $\begin{array}{l}\text { RI (Wetwitayaklung et al., 2009; } \\
\text { Yusoff et al., 2015) }\end{array}$ \\
\hline 19 & $\Upsilon$-muurolene & & & & 1,487 & RI (Yusoff et al., 2015) \\
\hline 20 & $\alpha$-selinene & & & & 1,493 & RI (Chen et al., 2012) \\
\hline 21 & $\alpha$-muurolene & & & & 1.495 & RI (Yusoff et al., 2015) \\
\hline 22 & $\Upsilon$ guaiene & & & & 1,501 & RI (Wetwitayaklung et al., 2009) \\
\hline 23 & $\alpha$-bulnesene & & & & 1,510 & RI (Ahmaed et al., 2017) \\
\hline 24 & $\alpha$-elemol & & & & 1,523 & RI (Yusoff et al., 2015) \\
\hline 25 & $\alpha$-agarofuran & & & & 1,534 & RI (Chen et al., 2012) \\
\hline 26 & Elemol & & & & 1,552 & RI (Chen et al., 2012) \\
\hline 27 & Epoxybulnesene & & & & 1,574 & RI (Wetwitayaklung et al., 2009) \\
\hline 28 & Caryophellene oxide & & & & 1,595 & RI (Ahmaed et al., 2017) \\
\hline 29 & Isoaromadendrene epoxide & & & & 1,607 & RI (Chen et al., 2012) \\
\hline 30 & Hinesol & & & & 1,612 & RI (Yusoff et al., 2015) \\
\hline 31 & 1,5-epoxy-nor-ketoguaiene & & & & 1,617 & $\begin{array}{l}\text { RI (Wetwitayaklung et al., 2009; } \\
\text { Yusoff et al., 2015) }\end{array}$ \\
\hline 32 & Agarospirol & & & & 1,636 & $\begin{array}{l}\text { RI (Ahmaed et al., 2017; Yusoff et al., } \\
\text { 2015) }\end{array}$ \\
\hline 33 & Jinko-eremol & & & & 1,642 & $\begin{array}{c}\text { RI (Wetwitayaklung et al., 2009; } \\
\text { Yusoff et al., 2015) }\end{array}$ \\
\hline 34 & Kusunol & & & & 1,648 & RI (Yusoff et al., 2015) \\
\hline 35 & $\alpha$-eudesmol & & & & 1,653 & RI (Yusoff et al., 2015) \\
\hline 36 & Bulnesol & & & & 1,660 & RI (Yusoff et al., 2015) \\
\hline 37 & Eudesm-7(11)-en-4 $\alpha$-ol & & & & 1,665 & RI (Chen et al., 2012) \\
\hline
\end{tabular}




\begin{tabular}{|c|c|c|c|c|c|c|}
\hline \multirow{2}{*}{ No } & \multirow{2}{*}{ Compounds } & \multicolumn{3}{|c|}{ Heat map of relative content $(\%)^{\mathrm{a}}$} & \multirow[t]{2}{*}{ 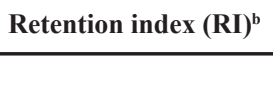 } & \multirow[t]{2}{*}{ Sources } \\
\hline & & M1 & M2 & M3 & & \\
\hline 38 & Dehydrojinkoh-eremol & & & & 1,670 & $\begin{array}{l}\text { RI (Wetwitayaklung et al., 2009; } \\
\text { Yusoff et al., 2015) }\end{array}$ \\
\hline 39 & $\begin{array}{c}\text { 6-Isopropenyl-4,8a-dimethyl } \\
\text { 1,2,3,5,6,7,8,8a-octahydronaphthalen- } \\
\text { 2-ol }\end{array}$ & & & & 1,676 & RI (Chen et al., 2012) \\
\hline 40 & $\alpha$-bisabolol & & & & 1,681 & RI (Yusoff et al., 2015) \\
\hline 41 & $\begin{array}{c}\text { 4,4,11,11-tetramethyl- } \\
\text { 7tetracyclo[6.2.1.0(3.8)0(3.9)]undecanol }\end{array}$ & & & & 1,690 & RI (Chen et al., 2012) \\
\hline 42 & Rotundone & & & & 1,704 & RI (Yusoff et al., 2015) \\
\hline 43 & Baimuxinal & & & & 1,708 & RI (Chen et al., 2012) \\
\hline 44 & Selina-3,11-dien-9-ol & & & & 1,722 & RI (Wetwitayaklung et al., 2009) \\
\hline 45 & Selina-4,11-dien-14-oic acid & & & & 1,725 & RI (Wetwitayaklung et al., 2009) \\
\hline 46 & Selina-3,11-dien-14-al & & & & 1,736 & RI (Chen et al., 2011) \\
\hline 47 & 9,11-eremophiladien-8-one & & & & 1,740 & RI (Wetwitayaklung et al., 2009) \\
\hline 48 & Selina-3,11-dien-14-ol & & & & 1,747 & RI (Yusoff et al., 2015) \\
\hline 49 & Guaia-1(10),11-dien-9-one & & & & 1,754 & RI (Chen et al., 2012) \\
\hline 50 & Selina-4,11-dien-14-al & & & & 1,757 & RI (Wetwitayaklung et al., 2009) \\
\hline 51 & Guaia-1(10),11-dien-15-ol & & & & 1,769 & RI (Wetwitayaklung et al., 2009) \\
\hline 52 & Dihydrokaranone & & & & 1,796 & RI (Wetwitayaklung et al., 2009) \\
\hline 53 & Guaia-1(10),11-dien-15-al & & & & 1,810 & RI (Yusoff et al., 2015) \\
\hline 54 & Oxo-agarospirol & & & & 1,824 & RI (Wetwitayaklung et al., 2009) \\
\hline \multirow[t]{2}{*}{55} & Eudesmol & & & & 1,882 & RI (Yusoff et al., 2015) \\
\hline & Fatty acid and alkanes & 5.412 & 3.376 & 1.744 & & \\
\hline 56 & Tetradecanal & & & & 1,590 & RI (Wetwitayaklung et al., 2009) \\
\hline 57 & Pentadecanal & & & & 1,696 & RI (Wetwitayaklung et al., 2009) \\
\hline 58 & 2-hexadecanone & & & & 1,782 & RI (Wetwitayaklung et al., 2009) \\
\hline 59 & Hexadecanol & & & & 1,855 & RI (Yusoff et al., 2015) \\
\hline 60 & Tridecanoic Acid & & & & 1,646 & RI (Wetwitayaklung et al., 2009) \\
\hline 61 & Tetradecanoic acid & & & & 1,773 & RI (Chen et al., 2012) \\
\hline 62 & Pentadecanoic acid & & & & 1,841 & RI (Wetwitayaklung et al., 2009) \\
\hline 63 & cis-5-Dodecenoic acid & & & & 1,858 & RI (Chen et al., 2012) \\
\hline
\end{tabular}

${ }^{\text {a} H i g h e s t ~ p e r c e n t a g e ~ o f ~ r e l a t i v e ~ c o n t e n t ~ o f ~ t h e ~ c o m p o u n d s ~ i s ~ s h o w n ~ a s ~ d a r k-b r o w n ~ c o l o r, ~ w h i l e ~ l o w e s t ~ p e r c e n t a g e ~ i s ~ s h o w n ~ a s ~ c l e a r-b r o w n ~ c o l o r . ~ R e l a t i v e ~ c o n t e n t ~ o f ~}$ the compounds were calculated from the peak area relative to the total peak.

${ }^{b} \mathrm{RI}$ values according to Hübschmann et al. (2009).

'Scale of heatmap color:

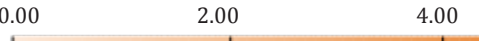

one. Based on these results, it was clear that the AEO from the decaying log demonstrated a high capacity for inhibiting the growth of $F$. solani. Agarwood formation is closely related to damage or physical wounding of an agarwood-producing tree by cutting, injury, microorganism, fire, pest or insect attack, and chemical (Dai et al., 2009; Rasool and Mohamed, 2016; Tan et al., 2019). The wounding and infection will trigger a defense mechanism to produce the major component of agarwood (i.e., sesquiterpenes and chromones) in parenchyma cells. Sesquiterpenes have been considered to contribute to physical restriction and chemical inhibition of microbes within vessels, consequently avoiding their spread (Zhang et al., 2014a, 2014b). This study confirmed that the growth of $F$. solani, a plant pathogen and an inducer of agarwood formation (Sitepu et al., 2011; Turjaman et al., 2016), was inhibited by $\mathrm{M} 1\left(\mathrm{MIG}_{50}, 0.5 \mathrm{mg} \mathrm{ml}^{-1}\right), \mathrm{M} 2\left(\mathrm{MIG}_{50}, 3.2 \mathrm{mg}\right.$ $\left.\mathrm{ml}^{-1}\right)$, and $\mathrm{M} 3\left(\mathrm{MIG}_{50}, 6.9 \mathrm{mg} \mathrm{ml}^{-1}\right)$ AEOs. These results showed a positive correlation between sesquiterpene contents on each AEO sample.

The antioxidant activity of AEO was conducted by using the DPPH assay and the results are presented in Table 2. This method was widely practiced because of its low cost, simplicity, reliability, reproducibility, and wide practice (Hidayat et al., 2018). The antioxidant activities $\left(\mathrm{IC}_{50}\right)$ for all samples ranged from $7.1 \mathrm{mg} \mathrm{ml}^{-1}$ to more than $200 \mathrm{mg} \mathrm{ml}^{-1}$. The $\mathrm{IC}_{50}$ value of M1 was higher than that of M2 $\left(>200 \mathrm{mg} \mathrm{ml}^{-1}\right)$ and $\mathrm{M} 3\left(7.8 \mathrm{mg} \mathrm{ml}^{-1}\right)$. According to this result, M1 and M3 AEOs showed their potential inhibition capacity for free radical molecules of DPPH. However, the inhibition capacity was categorized as very weak $(>0.2 \mathrm{mg}$ 


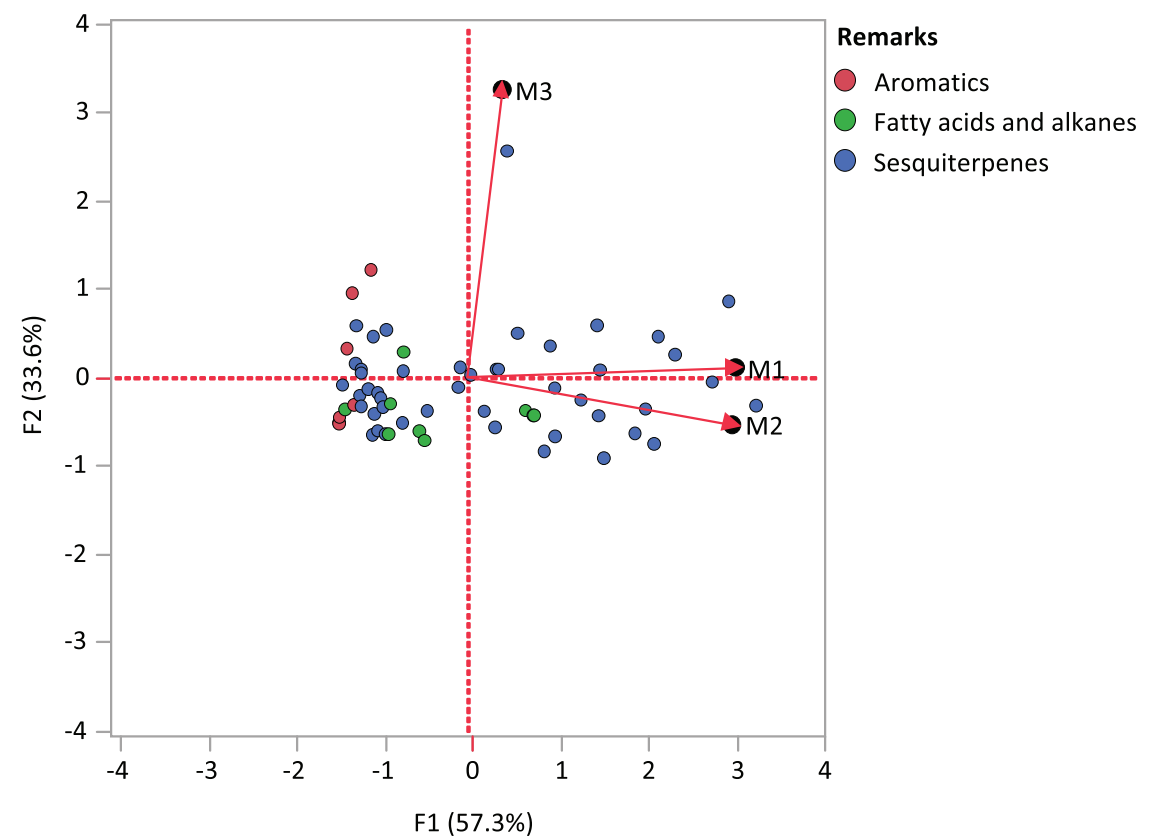

Figure 2. Biplot based on principal component analysis for the AEO compounds and the first (F1) and second (F2) principal components of the AEO GC spectrum.

Table 2. Potential bioactive assay of AEO as antifungal, antioxidant and anticancer.

\begin{tabular}{|c|c|c|c|c|c|c|c|}
\hline \multirow{2}{*}{\multicolumn{2}{|c|}{ Bioactive potential of AEO }} & \multicolumn{6}{|c|}{ Samples } \\
\hline & & \multicolumn{2}{|c|}{ M1 } & \multicolumn{2}{|c|}{ M2 } & \multicolumn{2}{|c|}{ M3 } \\
\hline \multicolumn{8}{|c|}{ Antifungus } \\
\hline 0.05 & $\mathrm{mg} \mathrm{ml}^{-1}$ & 38.1 & $\%$ & 42.5 & $\%$ & 26.4 & $\%$ \\
\hline 0.5 & $\mathrm{mg} \mathrm{ml}^{-1}$ & 54.0 & $\%$ & 47.1 & $\%$ & 37.9 & $\%$ \\
\hline 5 & $\mathrm{mg} \mathrm{ml}^{-1}$ & 58.7 & $\%$ & 50.6 & $\%$ & 48.3 & $\%$ \\
\hline \multicolumn{2}{|c|}{$\mathrm{MIG}_{50}$} & 0.5 & $\mathrm{mg} \mathrm{ml}^{-1}$ & 3.2 & $\mathrm{mg} \mathrm{ml}^{-1}$ & 6.9 & $\mathrm{mg} \mathrm{ml}^{-1}$ \\
\hline \multicolumn{8}{|c|}{ Antioxidant } \\
\hline 0.4 & $\mathrm{mg} \mathrm{ml}^{-1}$ & 10.4 & $\%$ & 5.6 & $\%$ & 10.6 & $\%$ \\
\hline 0.5 & $\mathrm{mg} \mathrm{ml}^{-1}$ & 12.9 & $\%$ & 6.6 & $\%$ & 11.2 & $\%$ \\
\hline 0.6 & $\mathrm{mg} \mathrm{ml}^{-1}$ & 16.1 & $\%$ & 6.9 & $\%$ & 16.3 & $\%$ \\
\hline \multicolumn{2}{|c|}{$\mathrm{IC}_{50}$} & 7.1 & $\mathrm{mg} \mathrm{ml}^{-1}$ & $>100$ & $\mathrm{mg} \mathrm{ml}^{-1}$ & 7.8 & $\mathrm{mg} \mathrm{ml}^{-1}$ \\
\hline \multicolumn{8}{|c|}{ Anticancer } \\
\hline 0.1 & $\mathrm{mg} \mathrm{ml}^{-1}$ & 0.8 & $\%$ & 8.1 & $\%$ & 15.1 & $\%$ \\
\hline $0.001^{\mathrm{a}}$ & $\mathrm{mg} \mathrm{ml}^{-1}$ & 91.9 & $\%$ & & & & \\
\hline
\end{tabular}

${ }^{a}$ Doxorubicin as the positive control.

$\mathrm{ml}^{-1}$ or $\left.>200 \mu \mathrm{g} \mathrm{ml}^{-1}\right)$ (Hidayat et al., 2018). The AEO originated from Aquilaria sinensis had been previously studied (Wang et al., 2018), in which the antioxidant activities $\left(\mathrm{IC}_{50}>60 \mathrm{mg} \mathrm{ml}^{-1}\right)$ were much weaker than vitamin $\mathrm{E}$ and butylated hydroxytoluene as well as AEOs used in this study. The antioxidant activities increased when purification was conducted to a single component of AEO. Purification of AEO from $A$. crassna that yielded $\beta$-caryophyllene showed high antioxidant activity with that equal to the value of ascorbic acid (Dahham et al., 2015).

The cytotoxicity of AEO was evaluated against MCF7 cells using the MTT assay. The inhibition percentage was analyzed, and the results are showed in Table 2 . The highest value of cytotoxicity activities (15.1\%) for all the samples at 0.1 $\mathrm{mg} \mathrm{ml} \mathrm{m}^{-1}$ was found in M3. The cytotoxicity of all samples was lower compared to the positive control $(91.9 \%)$. It indicated that all AEOs used in this study showed weak cytotoxic effects against MCF-7. The potential of anticancer properties from AEOs had also been previously studied (Dahham et al., 2015; Hashim et al., 2014; Ibrahim et al., 2011). The anticancer activity of AEO from A. malaccensis was determined in the range of 0.004-0.9 $\mathrm{mg} \mathrm{ml}^{-1}$ towards breast cancer (MCF-7) and human colon cancer cells (HCT116) (Hashim et al., 2014; Ibrahim et al., 2011). In this study, all AEOs showed anticancer properties against MCF-7 in the range of $0.8 \%-15.1 \%$ at the concentration of $0.1 \mathrm{mg} \mathrm{ml}^{-1}$. 
The AEO also contained some bioactive properties such as antifungal (Wetwitayaklung et al., 2009; Zhang et al., 2014a), antibacterial (Chen et al., 2012; Hoque et al., 2018; Wang et al., 2018; Wetwitayaklung et al., 2009), antioxidant (Dahham et al., 2015; Wang et al., 2018), and anticancer (Dahham et al., 2015; Hashim et al., 2014) properties. Several other studies had also identified AEO compounds containing bioactive properties, such as $\beta$-caryophyllene for its antioxidant, antimicrobial, and anticancer properties (Dahham et al., 2015); $\alpha$-guaiene showed antimicrobial and antiviral properties for influenza A (H2N2) virus (Swamy et al., 2016); gurjunene, eudesmol, and muurolene showed antiviral against avian influenza A virus, H5N1 (Ibrahim et al., 2015; Swamy et al., 2016); and gurjunene, muurolene, humulene, and eudesmol showed a potential to treat SARSCoV-2 (Silva et al., 2020). The results of this research supported previous findings and highlighted that AEO from the decaying $\log$ of the genus Gyrinops possessed several potential bioactive compounds.

\section{CONCLUSION}

This study is the first report on the chemical composition of AEO from a decaying log (Gyrinops spp.) originated from Papua Island of Indonesia. Fifty-eight compounds of essential oil were determined, and at least 10 compounds were responsible for specific agarwood odor. Essential oil showed promising antifungal activity $\left(\mathrm{MIG}_{50}, 0.5 \mathrm{mg} \mathrm{ml}^{-1}\right)$ against the phytopathogenic fungi F. solani, antioxidant activity $\left(\mathrm{IC}_{50}, 7.1 \mathrm{mg} \mathrm{ml}^{-1}\right)$, and anticancer activity $\left(0.8 \%\right.$ at concentration of $\left.0.1 \mathrm{mg} \mathrm{ml}^{-1}\right)$ against MCF-7 cells. Thus, AEO originated from the decaying log may be used as a supporting and promising candidate of the pharmaceutical agents for wider biotechnology applications in the future. Therefore, it is suggested that further work should focus on the isolation and identification of the mode of action of each bioactive substance.

\section{ACKNOWLEDGMENTS}

The authors acknowledge the Research Centre for Biomaterial, Indonesian Institute of Sciences (LIPI), and Dr. Dede Heri Yuli Yanto for their help in chemical identification analysis. They also thank their colleagues for helping and supporting the research work and critical comments to this manuscript. This research was partially supported by the Ministry of Environment and Forestry, the Republic of Indonesia.

\section{AUTHORS' CONTRIBUTIONS}

Asep Hidayat and Maman Turjaman designed, developed, and carried out the experiments, collected samples, analyzed and interpreted the data, contributed reagents, and wrote and edited the manuscript. Ruqoyah Qamyari carried out experiments and analyzed the data. Rinaldi Imanuddin analyzed the data. Dudi Tohir designed experiments and wrote and edited the manuscript. Raden Gunawan Hadi Rahmanto and Arida Susilowati wrote and edited the manuscript. All authors approved the final manuscript for publication.

\section{CONFLICT OF INTEREST}

The authors declare that this manuscript titled "Bioactive composition, antifungal, antioxidant, and anticancer potential of agarwood essential oil from decaying logs (Gyrinops spp.) of Papua Island (Indonesia)" is original, has not been published, and is not under consideration for publication elsewhere, and there are no conflicts of interest to disclose.

\section{ETHICAL APPROVALS}

This study does not involve experiments on animals or human subjects.

\section{PUBLISHER'S NOTE}

This journal remains neutral with regard to jurisdictional claims in published institutional affiliation.

\section{REFERENCES}

Abdullah A, Ismail NKN, Kadir TAA, Zain JM, Jusoh NA, Ali NM. Proceedings of the International Conference on Electrical Engineering and Informatics. Held at Institut Teknologi Bandung, Bandung, Indonesia, 2007.

Ahmaed DT, Kulkarni AD. Sesquiterpenes and chromones of agarwood: a review. Malaysian J Chem, 2017; 19(1):33-58.

Ahmaed DT, Mohammed M, Masaad AM, Tajuddin SN. Investigation of agarwood compounds in Aquilaria malaccensis \& Aquilaria Rostrata chipwood by using solid phase microextraction. Biomed J Sci Tech Res, 2017; 1(6):1-8.

Azah N, Ali M, Jalil M. Comparison of chemical profile of selected gaharu oils from Peninsular Malaysia. Malaysian J Anal Sci, 2008; 12(2):338-40.

Barden A, Anak NAA, Mulliken T, Song M. Heart of the matter: agarwood use and trade and cites implementation for Aquilaria malaccensis. Traffic International, Cambridge, UK, 2000.

Boissière $M$, van Heist $M$, Sheil D, Basuki I, Frazier $S$, Ginting U, Wan M, Hariadi B, Hariyadi H, Kristianto HD, Bemei J, Haruway R, Marien ERC, Koibur DPH, Watopa Y, Rachman I, Liswanti N. Pentingnya Sumberdaya Alam bagi Masyarakat Lokal di Daerah Aliran Sungai Mamberamo, Papua, dan Implikasinya bagi Konservasi. J Trop Ethnobiol, 2004; 1(2):76-95.

Chen HQ, Wei JH, Yang JS, Zhang Z, Yang Y, Gao ZH, Sui C, Gong B. Chemical constituents of agarwood originating from the endemic genus Aquilaria plants. Chem Biodivers, 2012; 9(2):236-50.

Chen H, Yang Y, Xue J, Wei J, Zhang Z, Chen H. Comparison of Compositions and Antimicrobial Activities of Essential Oils from Chemically Stimulated Agarwood, Wild Agarwood and Healthy Aquilaria Sinensis (Lour.) Gilg Trees. Molecules, 2011; 16(6), 4884-96.

Dahham SS, Tabana YM, Iqbal MA, Ahamed MBK, Ezzat MO, Majid ASA, Majid AMSA. The anticancer, antioxidant and antimicrobial properties of the sesquiterpene $\beta$-caryophyllene from the essential oil of Aquilaria crassna. Molecules, 2015; 20(7):11808-29.

Dai HF, Liu J, Zeng YB, Han Z, Wang H, Mei WL. A new 2-(2-phenylethyl)chromone from Chinese eaglewood. Molecules, 2009; 14(12):5165-8.

Dwiprabowo H, Tampubolon AP, Komar TE. The prospect of agarwood market. Center for Forest Biotechnology and Tree Improvement, Yogyakarta, Indonesia, 2016.

Faizal A, Wydia A, Azar P, Turjaman M, Esyanti RR. Fusarium solani induces the formation of agarwood in Gyrinops versteegii (Gilg.) Domke branches. Symbiosis, 2020; 18:15-23.

Gong LJ, Guo SX. Endophytic fungi from Dracaena cambodiana and Aquilaria sinensis and their antimicrobial activity. African J Biotechnol, 2009; 8(5):731-6.

Hashim YZH, Abbas P, Amid A. Screening of anticancer activity from agarwood essential oil. Pharmacognosy Res, 2014; 6(3):191-4.

Hidayat A, Iswanto AH, Susilowati A, Rachmat HH. Radical scavenging activity of kemenyan resin produced by an Indonesian native plant, Styrax sumatrana. J Korean Wood Sci Technol, 2018; 46(4):346-5.

Hidayat A, Turjaman M, Faulina SA, Ridwan F, Najmulah, Irawadi TT, Iswanto AH. Antioxidant and antifungal activity of endophytic fungi associated with agarwood trees. J Korean Wood Sci Technol, 2019; 47(4):459-71. 
Hoque NM, Mondal FM, Khan HMM. Chemical composition and antimicrobial activity of the essential oils from Aquillaria malaccensis in Bangladesh. Haya Saudi J Life Sci, 2018; 3:600-8.

Hübschmann H, Eidhammer I, Flikka K, Martens L. Handbook of GC/MS fundamentals and applications. WILEY-VCH Verlag GmbH \& Co. KGaA, Weinheim, Germany, 2009.

Ibrahim AH, Majid AMSA, Rahman NNA, Salah, KMA, Kadir MOA. Separation and fractionation of Aquilaria malaccensis oil using supercritical fluid extraction and the cytotoxic properties of the extracted oil. In: Saravacos G (ed.) 11th International congress on engineering and food. Elsevier Procedia 1953-1959, Athens, Greece, 2011.

Ibrahim NA, El-hawary SS, Mohammed MMD, Farid MA, Abdel-Wahed NAM, Ali MA, El-abd EAW. Chemical composition, antiviral against avian influenza (H5N1) virus and antimicrobial activities of the essential oils of the leaves and fruits of Fortunella margarita, Lour. Swingle, Growing in Egypt. J Appl Pharm Sci, 2015; 5(1):6-12.

Ishihara M, Tsuneya $\mathrm{T}$, Uneyama $\mathrm{K}$. Components of the agarwood smoke on heating. J Essent Oil Res, 1993b; 5(4):419-23.

Ishihara $\mathrm{M}$, Tsuneya $\mathrm{T}$, Uneyama $\mathrm{K}$. Components of the volatile concentrate of agarwood. J Essent Oil Res, 1993a; 5(3):283-9.

Ismail N, Ali NAM, Jamil M, Rahiman MHF, Tajuddin SN, Taib MN. A review study of agarwood oil and its quality analysis. J Teknol, 2014; 68(1):37-42.

Jong PL, Tsan P, Mohamed R. Gas chromatography-mass spectrometry analysis of agarwood extracts from mature and juvenile Aquilaria malaccensis. Int J Agric Biol, 2014; 16(3):644-8.

Mosmann T. Rapid colorimetric assay for cellular growth and survival: application to proliferation and cytotoxicity assays. J lmmunol Methods, 1983; 65(1-2):55-63.

Mulyaningsih T, Yamada I. Notes on some species of agarwood in Nusa Tenggara, Celebes and West Papua. In: Koji T, Kosuke M, Masaaki O, Katsuya O, Jun A, Masahiro I, (ed.). Natural resource management and socio-economic transformation under the decentralization in Indonesia: toward Sulawesi area studies. CSEAS Kyoto University, Kyoto, Japan, pp 365-72, 2007.

Naef R. The volatile and semi-volatile constituents of agarwood, the infected heartwood of Aquilaria species: a review. Flavour Fragr J, 2011; 26(2):73-87.

Perdanahardja GH. Aquilaria spp. harvest; chain of custody and its sustainability in East Kalimantan. University of Indonesia, Depok, 2008.

Philippe S, Souaïbou F, Jean-pierre N, Brice F, Paulin A, Issaka $\mathrm{Y}$, Dominique $\mathrm{S}$. Chemical composition and in vitro antifungal activity of Zingiber officinale essential oil against foodborne pathogens isolated from a traditional cheese wagashi produced in Benin. Int J Biosci, 2012; 2(9):20-8.

Radzi NC, Harip MKZ, Musa M, Zaki NAM, Alwi H, Rodhi MNM, Hamid KHK. Analysis of sesquiterpenes in agarwood essential oil from hydrodistillation process. Malaysian J Anal Sci, 2018; 22(2):353-7.

Rasool S, Mohamed R. Understanding agarwood formation and its challenges. In: Mohamed R (ed.). Depelompent of agarwood induction tecnology using endophytic fungi. Springer, Singapore, pp 36-56, 2016.

Saikia P, Khan ML. Population structure and regeneration status of Aquilaria malaccensis Lam. in homegardens of Upper Assam, Northeast India. Trop Ecol, 2013; 54(1):1-13.

Semiadi G, Wiriadinata EB, Darnaedi D. Rantai pasokan produk tumbuhan gaharu (Aquilaria spp.) asal Merauke, Papua. Bul Plasma Nutfah, 2010; 16(2):150-9.

Silva JKR, Figueiredo PLB, Byler KG, Setzer WN. Essential oils as antiviral agents. Potential of essential oils to treat SARS-CoV-2 infection: an in-silico investigation. Int J Mol Sci, 2020; 21(10):1-37.

Sitepu IR, Santoso E, Siran SA, Turjaman M. Fragrant wood gaharu: when the wild can no longer provide. ITTO and FORDA, Bogor, Indonesia, 2011.

Soehartono T, Newton A. Conservation and sustainable use of tropical trees in the genus Aquilaria II. The impact of gaharu harveting in Indonesia. Biol Conserv, 2001; 97(1):29-41.

Subasinghe SMCUP, Hettiarachchu DS, Rathnamalla E. Agarwood-type resin from Gyrinops walla gaertn: a new discovery. J Trop Environ, 2012; 2(2):43-8.
Sugiyanto K, Hidayat A, Rachmat HH, Turjaman M, Alhamd L, Widodo RMW, Machmudah F, Hartantri H, Ardiyani M, Wardani W, Wiradinata H, Haryono M. Identifikasi Jenis Pohon Berdasarkan Struktur Anatomi Gaharu Lumpur (Decaying Log) dari Papua. Kementerian Lingkungan Hidup dan Kehutanan, Jakarta, Indonesia, 2018.

Swamy MK, Akhtar MS, Sinniah UR. Antimicrobial properties of plant essential oils against human pathogens and their mode of action: an updated review. Evid Based Complement Alternat Med, 2016; 2016:1-21.

Tajuddin SN, Muhamad NS, Yarmo A, Yusoff MM. Characterization of the chemical constituents of agarwood oils from Malaysia by comprehensive two-dimensional gas chromatography-time-offlight mass spectrometry. Mendeleev Commun, 2013; 23(1):51-2.

Tajuddin SN, Yusoff MM. Chemical composition of volatile oils of Aquilaria malaccensis (Thymelaeaceae) from Malaysia. Nat Prod Commun Chem, 2010; 5:1965-8.

Tan CS, Isa NM, Ismail I, Zainal Z. Agarwood induction: current developments and future Perspectives. Front Plant Sci, 2019; 10:122.

Thuy DTT, Tuyen TT, Thuy TTT, Minh PTH, Tran QT, Long PQ, Nguyen DC, Bach LG, Chien NQ. Isolation process and compound identification of agarwood essential oils from Aquilaria crassna cultivated at three different locations in Vietnam. Processes, 2019; 7:432.

Turjaman M, Hidayat A, Santoso E. Depelompent of agarwood induction tecnology using endophytic fungi. In: Mohamed R (ed.). Depelompent of agarwood induction tecnology using endophytic fungi. Springer, Singapore, pp 57-71, 2016.

Wang MR, Li W, Luo S, Zhao X, Ma CH, Liu SX. GC-MS study of the chemical components of different Aquilaria sinensis (Lour.) gilgorgans and agarwood from different Asian countries. Molecule, 2018; 23(9):2168.

Wetwitayaklung $\mathrm{P}$, Thavanapong $\mathrm{N}$, Charoenteeraboon $\mathrm{J}$. Chemical constituents and antimicrobial activity of essential oil and extracts of heartwood of Aquilaria crassna obtained from water distillation and supercritical fluid carbon dioxide extraction. Silpakorn U Sci Technol J, 2009; 3(1): 25-33.

Xu Y, Zhang Z, Wang M, Wei J, Chen H, Gao Z, Sui C, Luo $\mathrm{H}$, Zhang X, Yang Y, Meng H, Li W. Identification of genes related to agarwood formation: transcriptome analysis of healthy and wounded tissues of Aquilaria sinensis. BMC Genomics, 2013; 14:227.

Yoswathana N, Eshiaghi MN, Jaturapornpanich K. Enhancement of essential oil from agarwood by subcritical water extraction and pretreatments on hydrodistillation. Int Sch Sci Res Innov, 2012; 6(5):453-9.

Yusoff NAM, Tajuddin SN, Hisyam A, Omar NAM. Agarwood essential oil: study on optimum parameter and chemical compounds of hydrodistillation extraction. J Appl Sci Agric, 2015; 10(5):1-5.

Zhang XL, Liu YY, Wei JH, Yang Y, Zhang Z, Huang JQ, Chen HQ, Liu YJ. Production of high-quality agarwood in Aquilaria sinensis trees via whole-tree agarwood-induction technology. Chinese Chem Lett, 2012; 23(6):727-30.

Zhang Z, Han X, Wei J, Xue J, Yang Y, Liang L, Li X, Guo $\mathrm{Q}, \mathrm{Xu} \mathrm{Y}, \mathrm{Gao} \mathrm{Z}$. Compositions and antifungal activities of essential oils from agarwood of Aquilaria sinensis (Lour.) gilg induced by Lasiodiplodia theobromae (Pat.) Griffon. Maubl J Braz Chem Soc, 2014a; 25(1): 20-6.

Zhang Z, Wei J, Han X, Liang L, Yang Y, Meng H, Xu Y, Gao $Z$. The sesquiterpene biosynthesis and vessel-occlusion formation in stems of Aquilaria sinensis (lour.) gilg trees induced by wounding treatments without variation of microbial communities. Int J Mol Sci, 2014b; 15(12): 23589-603.

\section{How to cite this article:}

Hidayat A, Turjaman M, Qamyari R, Imanuddin R, Tohir D, Rahmanto RGH, Susilowati A. Bioactive composition, antifungal, antioxidant, and anticancer potential of agarwood essential oil from decaying logs (Gyrinops spp.) of Papua Island (Indonesia). J Appl Pharm Sci, 2021; 11(10):070-078. 